\title{
Guest Editorial: Corporate Social Responsibility in Controversial Industry Sectors
}

\author{
Adam Lindgreen • François Maon • \\ Jon Reast $\cdot$ Mirella Yani-De-Soriano
}

(C) Springer Science+Business Media Dordrecht 2012

Corporate social responsibility (CSR) has gained unprecedented prominence in academic and business spheres alike (Kotler and Lee 2005; McWilliams et al. 2006); more than ever before, it is necessary for organizations to define their roles in society and apply social, environmental, ethical, and responsible standards to their businesses (Lichtenstein et al. 2004; Lindgreen et al. 2009). Beyond the moral arguments and value-based debates that characterize the complex landscapes of CSR-related concepts and ideas (Garriga and Melé 2004), corporate commitment to socially responsible management practices is associated with a conviction that the failure to meet basic social rules or expectations pertaining to the way organizations behave can result in perceptions of those organizations as illegitimate (Campbell 2007; Sethi 1975). Increased engagement in CSR-related policies and initiatives, and associated communication efforts, provide a way for organizations to circumvent situations and practices that might be perceived as unethical or unsustainable or that "alienate the

\footnotetext{
A. Lindgreen $(\varangle) \cdot$ M. Yani-De-Soriano

Cardiff Business School, Cardiff University, Aberconway

Building, Colum Drive, Cardiff CF10 3EU, UK

e-mail: lindgreena@cardiff.ac.uk

M. Yani-De-Soriano

e-mail: yani-de-sorianoM@cardiff.ac.uk

F. Maon

Department of Management, IESEG School of Management

(LEM-CNRS), 3 rue de la Digue, 59000 Lille, France

e-mail: f.maon@ieseg.fr

J. Reast

Bradford University School of Management, University

of Bradford, Emm Lane, Bradford BD9 4JL, UK

e-mail: j.reast@bradford.ac.uk
}

organization from the rest of society, resulting in reduced reputation, increased costs, and decreasing shareholder value through erosion of its license to operate" (Hill 2001, p. 32).

In such a context, a clear question arises: How can organizations in "controversial industry sectors," which often are marked by social taboos, moral debates, and political pressures, maintain reasonable, socially responsible standards? For industry sectors typically characterized as "sinful" (e.g., tobacco, gambling, weapons, alcohol, adult entertainment), as well as for those that inherently entail persistent or emerging environmental, social, or ethical issues (e.g., nuclear, oil, cement, biotech), this special issue aims to provide some answers and define ways they can adopt CSR-related policies and practices to meet their public legitimacy requirements.

In their seminal work in this area, Wilson and West (1981, p. 92) describe controversial industry sectors as those related to "products, services or concepts that for reasons of delicacy, decency, morality, or even fear elicit reactions of distaste, disgust, offence or outrage when mentioned or when openly presented." Although attitudes to such industry sectors vary by culture (Waller et al. 2005), they and their products or services often come under close scrutiny by external actors who view them as morally corrupt (de Colle and York 2008), unethical (Byrne 2010), offensive (Fam and Waller 2003), or exemplary of aberrant behavior (Budden and Griffin 1996)—perhaps regardless of their actual or latent harm to society, the environment, or individuals (Demont et al. 2004; Kindt 2006; Pratten 2007). Many such industry sectors affect more vulnerable groups in society and local communities disproportionately (Bristow 2007; Cook et al. 2003; Nikiforuk 2008) yet remain legal, provide tax revenues for governments, and meet consumer demands. 
Thus, this special issue considers the relationship between controversial industry sectors and CSR. Do organizations in these industries use CSR to present themselves in a positive manner-doing well by doing good-and deflect negative perceptions and associations? Should such a relationship be approached as an appropriate association, or is it rather a cynical attempt to legitimize questionable offerings and fool stakeholders?

Despite some recent research on the topic (e.g., Banerjee and Bonnefous 2011; Byrne 2007; Frynas 2005; Palazzo and Richter 2005; Runde-Thiele et al. 2008; Yoon et al. 2006), a general consensus among academics and practitioners suggests that we have only just begun to understand how organizations in controversial industry sectors gain or sneak legitimacy through their CSR policies and initiatives. Different legitimacy approaches have been investigated, but research gaps remain, and new fields need to be explored. This special issue addresses these lacunae.

\section{The Structure of the Special Issue}

Seven articles have been included in this special issue. To begin, in "Do Environmental CSR Initiatives Serve Organizations' Legitimacy in the Oil Industry? Exploring Employees' Reactions through Organizational Identification Theory," Kenneth De Roeck and Nathalie Delobbe consider what causes employees to respond favorably when the controversial company that employs them-in this case, a petrochemical firm-initiates CSR. With a survey of more than 150 employees, they reveal that perceived CSR encourages organizational identification, though this link is mediated by levels of organizational trust and moderated by several contingency factors. Accordingly, this study suggests that CSR serves another purpose for firms in controversial industries, namely, to improve their employee relationships.

Shuili Du and Edward T. Vieira also investigate the oil industry in "Striving for Legitimacy through Corporate Social Responsibility: Insights from Oil Companies," though they use a case study methodology rather than a survey. Through case studies of the websites of six oil companies, the authors examine both strategies and communication related to CSR. The easily accessible information on the corporate websites revealed that all six companies pursued CSR activities. Not only did these activities focus on varied stakeholders, but the oil firms also adopted multiple tactics to enhance the credibility of their messages. This article thereby shows that it is impossible to separate business strategy, CSR practices, and CSR communication when it comes to understanding how firms in controversial industries attempt to achieve legitimacy.
In contrast, Marian Eabrasu posits, in "A Moral Pluralist Perspective on Corporate Social Responsibility: From Good to Controversial Practices," that CSR practices often seem uncontroversial, at least at face value. Thus conventional CSR literature offers a list of good practices (e.g., minimizing pollution, granting human rights to workers), but approaching the topic from a moral perspective suggests a different view. Moral pluralism reveals that any good practice entails varied moral concepts (e.g., responsibility, harm, intention, consequences) with practically incomprehensible meanings. In the atypical discipline of CSR, all topics thus may be controversial.

Perhaps to address such variance, in "Does CSR Reduce Firm Risk? Evidence from Controversial Industry Sectors," Jo Hoje and Na Haejung propose and test a firm risk reduction hypothesis across several controversial industries (e.g., gambling, tobacco, alcohol). Specifically, they confirm that engagement in CSR reduces firm risk. In a further comparison of controversial with noncontroversial firms, they show that this risk reduction effect is more significant, both economically and statistically, for companies in controversial industries. The risk-averse managers of firms in such industries thus can use CSR to manage the risk they consistently face.

These managers also can find guidance in "Strategic Corporate Social Responsibility in Controversial Industry Sectors: The Social Value of Harm Minimization," by Margaret Lindorff, Elizabeth Prior Jonson, and Linda McGuire. This article recommends the use of a utilitarian justification, based on the reasoning that the legal, regulated provision of controversial goods is preferable to and safer than an illegal, unregulated supply (e.g., through a black market). In order to ensure their utility though, these companies must go beyond minimizing harm and maximize good. The authors propose a model for firms in controversial sectors to help them choose socially responsible acts that reflect their strategic focus.

Justin Tan and Anna E. Tan take a slightly different approach in their definition of controversial industries in "Business Under Threat, Technology Under Attack, Ethics Under Fire: The Experience of Google in China." They demonstrate that digital communications provide sites of substantive CSR conflict, as exemplified by the case of Google's 2010 entry into China. The digital firm faced various ethical, political, and cultural questions when China's central government required it to limit access to some material; its response-namely, to withdraw from mainland China and function through Hong Kong-was both difficult to reach and controversial. More broadly, according to these authors, this example raises challenging questions about the efficacy with which global firms can attain international growth but still maintain their CSR standards in varied, highly sensitive foreign environments. 
Finally, in considering another digital industry, Mirella Yani-de-Soriano, Uzma Javed, and Shumaila Yousafzai question if online gambling companies really can attain CSR. In their article, "Can an Industry Be Socially Responsible if its Products Harm Consumers? The Case of Online Gambling," the authors report on a survey of 209 online gamblers that reveals the depth and extent of harm due to problem gambling. This harm is closely related to the time spent online, both gambling and in other activities, as well as peer gambling and binge drinking. Faced with such damages, the authors argue that online gambling cannot ever attain true CSR, but the sites can meet ethical and legal obligations and thereby achieve legitimacy. Concerned that online gambling companies cannot be expected to police themselves, this article recommends international, legislative policies that mandate fully implemented CSR policies, limit advertising, and ban misleading promotional communications.

Acknowledgments We take this opportunity to thank all those who have contributed to this special issue of Journal of Business Ethics. First, we thank the colleagues and reviewers who devoted their valuable time to provide timely feedback to the authors, suggesting ways to improve their contributions. Working with such professional reviewers made our guest editing experience easy and enjoyable. Second, we extend a special thanks to the Editor-in-Chief, Professor Alex Michalos, and the Special Issues Editor, Professor Thomas Maak, for this opportunity to guest edit this special issue of Journal of Business Ethics. Third, and perhaps most important, we warmly thank all of the authors who submitted their manuscripts for consideration. We appreciate and are grateful for their desire to share their knowledge and experience with the journal's readers by putting their views forward for possible challenge by their peers. We are confident that the articles in this special issue contribute to our understanding of controversial industries; we look forward to reading more research on this important and interesting topic.

\section{References}

Banerjee, B., \& Bonnefous, A.-M. (2011). Stakeholder management and sustainability strategies in the French Nuclear Industry. Business Strategy and the Environment, 20(2), 124-140.

Bristow, M. (2007). Losing streak. Hospital Doctor, May 3, 30-31.

Budden, M. C., \& Griffin, T. F. (1996). Explorations \& applications of aberrant consumer behaviour. Psychology \& Marketing, 13(8), 739-740.

Byrne, E. (2007). Assessing arms makers corporate social responsibility. Journal of Business Ethics, 74(2), 201-217.

Byrne, E. (2010). The U.S. military-industrial complex is circumstantially unethical. Journal of Business Ethics, 95(2), 153-165.

Campbell, J. L. (2007). Why would corporations behave in socially responsible ways? An institutional theory of corporate social responsibility. Academy of Management Review, 32(3), 946-967.

Cook, B., Wayne, G., Keithly, L., \& Connolly, G. (2003). One size does not fit all: How the tobacco industry has altered cigarette design to target consumer groups with special psychological needs. Addiction, 98(11), 1547-1561.

de Colle, S., \& York, J. (2008). Why wine is not glue: The unresolved problem of socially responsible investing. Journal of Business Ethics, 85(1), 83-95.

Demont, M., Wesseler, J., \& Tollens, E. (2004). Biodiversity versus transgenic sugar beets: The one euro question. European Review of Agricultural Economics, 31(1), 1-18.

Fam, K. S., \& Waller, D. S. (2003). Advertising offensive products in the Asia-Pacific: What makes them offensive? Journal of Business Ethics, 48(3), 237-250.

Fynas, J. (2005). The false developmental promise of corporate social responsibility: Evidence from multinational oil companies. International Affairs, 81(3), 581-598.

Garriga, E., \& Melé, D. (2004). Corporate social responsibility theories: Mapping the territory. Journal of Business Ethics, 53(1), 51-71.

Hill, J. (2001). Thinking about a more sustainable business: An indicators approach. Corporate Environmental Strategy, 8(1), 30-38.

Kindt, J. W. (2006). Testimony before the subcommittee on crime, terrorism, and homeland security. United States House of Representatives. Legislative Hearing on H.R 4777: The Internet Gambling Prohibition Act, April 5.

Kotler, P., \& Lee, N. (2005). Corporate social responsibility: Doing the most good for your company and your cause. Hoboken, NJ: Wiley.

Lichtenstein, D. R., Drumwright, M. E., \& Braig, B. M. (2004). The effect of corporate social responsibility on customer donations to corporate-supported nonprofits. Journal of Marketing, 68(4), $16-32$.

Lindgreen, A., Swaen, V., \& Johnston, W. J. (2009). Corporate social responsibility: An empirical investigation of U.S. organizations. Journal of Business Ethics, 85(Suppl. 2), 303-323.

McWilliams, A., Siegel, D. S., \& Wright, P. M. (2006). Corporate social responsibility: Strategic implications. Journal of Management Studies, 43(1), 1-18.

Nikiforuk, A. (2008). Tar sands: Dirty oil and the future of a continent. Vancouver, BC: Greystone Books.

Palazzo, G., \& Richter, U. (2005). CSR business as usual? The case of the tobacco industry. Journal of Business Ethics, 61(4), 387-401.

Pratten, J. (2007). Reporting on responsible drinking: A study of the major UK pub owning companies. Business Ethics: A European Review, 16(1), 62-70.

Rundle-Thiele, S., Ball, K., \& Gillespie, M. (2008). Raising the bar: From corporate social responsibility to corporate social performance. Journal of Consumer Marketing, 25(4), 245-253.

Sethi, S. P. (1975). Dimensions of corporate social performance: An analytical framework. California Management Review, 17(3), 58-64.

Waller, D. S., Fam, K. S., \& Erdogan, B. Z. (2005). Advertising of controversial products: A cross-cultural study. Journal of Consumer Marketing, 22(1), 6-13.

Wilson, A., \& West, C. (1981). The marketing of "unmentionables". Harvard Business Review, 51(1), 91-102.

Yoon, Y., Gürhan-Canli, Z., \& Schwarz, N. (2006). The effect of corporate social responsibility (CSR) activities on companies with bad reputations. Journal of Consumer Psychology, 16(4), 377-390. 